\title{
UNICORN LEATHERJACKET FILEFISH, ALUTERUS MONOCEROS (ACTINOPTERYGII: TETRAODONTIFORMES: MONACANTHIDAE): FIRST RECORD OFF THE TUNISIAN COAST AND CONFIRMED OCCURRENCE IN THE MEDITERRANEAN SEA
}

\author{
Jamila BEN SOUISSI ${ }^{1 *}$, Wassim BOUGHEDIR ${ }^{1}$, Mohamed Mourad BEN AMOR ${ }^{2}$, \\ and Christian CAPAPÉ ${ }^{3}$ \\ ${ }^{1}$ Département des Ressources Animales, Halieutiques et des Technologies Agroalimentaires, \\ Institut National Agronomique de Tunisie, Tunis, Tunisia \\ ${ }^{2}$ Institut National des Sciences et Technologies de la Mer, port de pêche, 2025 La Goulette, Tunisia \\ ${ }^{3}$ Laboratoire d'Ichtyologie, case 104, Université Montpellier II, Sciences et Techniques du Languedoc, \\ 34095 Montpellier cedex 5, France
}

Ben Souissi J., Boughedir W., Ben Amor M.M., Capapé C. 2011. Unicorn leatherjacket filefish, Aluterus monoceros (Actinopterygii: Tetraodontiformes: Monacanthidae): first record off the Tunisian coast and confirmed occurrence in the Mediterranean Sea. Acta Ichthyol. Piscat. 41 (3): 247-250.

\begin{abstract}
Investigations conducted off the northern Tunisian coast (central Mediterranean) allowed the authors to collect a male of the unicorn leatherjacket filefish, Aluterus monoceros (L.). The specimen is described in this note, including morphometric measurements and meristic counts. This finding constitutes the first record of A. monoceros off the Tunisian coast and the second record for the Mediterranean Sea. The occurrence of this species in the area and the Mediterranean Sea is discussed and commented.
\end{abstract}

Keywords: Actinopterygii, Osteichthyes, Monacanthidae, Aluterus monoceros, first record, Tunisian coast, Mediterranean

The unicorn leatherjacket filefish, Aluterus monoceros (L.), is a widespread species, known from the western Indian Ocean, the eastern Pacific, and the both sides of the Atlantic (De La Cruz-Agüero et al. 2007). Two specimens were recorded from the eastern Atlantic - the first one from the Bay of Biscay (Quéro and Laborde 1996, Quéro et al. 2003) and the other from the southern Iberian Peninsula — off Chipiona, close to Cádiz (Galeote et al. 1998). South of the Gibraltar Strait — on the western African coastA. monoceros is rare (Harmelin-Vivien and Quéro 1990), whereas much more southward-in South African waters - it has been reported as rather abundant (Smith and Heemstra 1986).

This first Mediterranean record of the unicorn leatherjacket filefish was reported by Guallart and Vicent (2009). It was an adult male, captured on 28 March 2000, with harpoon gun at a depth of $4 \mathrm{~m}$, in the waters surrounding Chafarinas Islands, a small archipelago located in south-western Mediterranean. Guallart and Vicent (2009) suggested an Atlantic origin of the specimen, due to the proximity to the Strait of Gibraltar. Since this capture, no new record of $A$. monoceros was reported to date in the Mediterranean Sea.
Investigations conducted during the last decade in the Tunisian waters allowed us to collect a specimen of A. monoceros in the area. The Tunisian specimen was captured on 30 December 2010 by a trammel net, approximately at a depth of $45 \mathrm{~m}$, on rocky coralligenous bottom, between the Islands Zembra and Zembretta (lat $37^{\circ} 06^{\prime} 38^{\prime \prime} \mathrm{N}$, long $10^{\circ} 50^{\prime} 49^{\prime \prime} \mathrm{E}$ ) (Fig. 1), concomitantly with several greater amberjacks, Seriola dumerilii (Risso, 1810). Soon after the capture, the fresh specimen was identified, photographed, measured to the nearest millimetre, and weighed to the nearest decigram (Fig. 2). Morphometric measurements, percentages of standard length (\%SL) and meristic counts were carried out following Berry and Vogele (1961), Quéro and Laborde (1996), Galeote et al. (1996), De La Cruz-Agüero et al. (2007) and Guallart and Vicent (2009) (Table 1). The specimen is preserved in $10 \%$ buffered formalin in the Ichthyological Collection of the Institut National Agronomique of Tunisia, Tunis, receiving the catalogue number: Alu-mon. 01 .

The Tunisian A. monoceros measured $528 \mathrm{~mm}$ (total length) and weighed $1683.4 \mathrm{~g}$, its eviscerated mass was $1527.9 \mathrm{~g}$ and the liver mass, $83.4 \mathrm{~g}$. The gonads weighed $3.3 \mathrm{~g}$, they were thread-like and portions of fresh tissue

\footnotetext{
${ }^{*}$ Correspondence: Dr. Jamila Ben Souissi, Département des Ressources Animales, Halieutiques et des Technologies Agroalimentaires, Institut National Agronomique de Tunisie, 43 avenue Charles Nicolle, cité Mahrajène, 1082 Tunis, Tunisia, phone : 0021671287110 e-mail : bensouissi.jamila@inat.agrinet.tn.
} 
were immediately examined under an optical microscope, showing that the specimen was an adult male in resting phase. The gut contained remains of completely digested food, and remains of unidentifiable mollusc species.

The specimen was identified as follows: body slightly high and compressed, 2.67 times in standard length. First dorsal fin with single spine, long and feeble, second spine not visible. Pre-dorsal length, 1.77 and 2.07 times in standard length and total length, respectively. Anal fin opposite to second dorsal fin and similar in shape. Small round pectoral fin. Pelvic fin absent. Caudal fin slightly emarginated, its length 1.50 times in head length. Upper head profile rather straight. Ventral head profile anteriorly concave becoming convex. Small eye at upper part of head. Slit-like gill opening in front of pectoral fin base. Smooth leathery skin. Body greyish, with spots slightly darker. Fins greyish with yellow touch.

General morphology, colour, morphometric measurements with percentages of standard length and meristic counts are in agreement with previous descriptions of A. monoceros from other regions (Berry and La Vogele 1961, Al-Baharna 1986, Quéro and Laborde 1996, Galeote et al. 1996, De La Cruz-Agüero et al. 2007, Guallart and Vicent 2009) (Table 1) and confirm the occurrence of the species in Tunisian waters. Additionally, this finding constitutes the first record of the species in the area, and hence it could be included in the Tunisian ichthyofauna (Bradaï et al. 2004), and the second Mediterranean record.

A. monoceros is the second species belonging to the family Monacanthidae found off the Tunisian coast, the first one being a Lessepsian migrant, the reticulated leatherjack, Stephanolepis diaspros Fraser-Brünner, 1940, which is at present successfully established throughout the area (Ben Amor and Capapé 2008). S. diaspros can be distinguished from its confamilial species in the Tunisian waters, by the first ray in the second dorsal fin which is often filamentous, the body depth 1.8-2.0 times in standard length, and the rough shagreen-like skin composed of very small scales with delicate spinules, caudal peduncle of the male consists of a series of horny patches in several rows.

A. monoceros and S. diaspros inhabit same bottoms and feed on same preys with probable overlaps in ecological

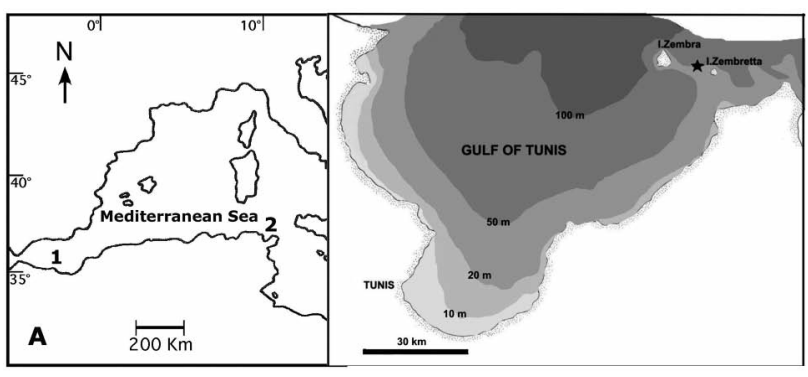

Fig. 1. Maps of western Mediterranean Sea showing the two capture sites of Aluterus monoceros: 1) Off Chafarinas Islands, small archipelago close to the Moroccan coast (Guallart and Vicent 2009); 2) In the Gulf of Tunis, northern Tunisia (this study: capture site (black star) between Islands Zembra and Zembretta)

niches and diet (Gomez-Canchong et al. 2004, LopezPeralta and Arcila 2002). Consequently, an interspecific competition pressure between both species could not be excluded, preventing a successful establishment of $A$. monoceros in its new area, especially in southern areas where $S$. diaspros is at present considered as both frequent and abundant (Zouari-Ktari et al. 2008), conversely rare records were reported northward (Ben Amor and Capapé 2008).

This second record of $A$. monoceros in a region located approximately $1500 \mathrm{~km}$ from the Strait of Gibraltar constitutes the easternmost extension range of the species in the Mediterranean Sea. It shows that A. monoceros is prone to large migrations which explains its worldwide distribution. The specimen described in the present paper most probably originated from the eastern Atlantic, entering through the Strait of Gibraltar. Although, A. monoceros occurs in the Indian Ocean, a migration through Suez Canal remains improbable. No specimen was found in the eastern Mediterranean (Golani et al. 2006), where $S$. diaspros was successfully established several decades ago (Quignard and Tomasini 2000, Golani et al. 2002).

Salameh et al. (2009) note that most of migrant species originating from eastern Atlantic remain rare or are considered as vagrant in their new habitat. In contrast, Ben Raïs Lasram and Mouillot (2009) note that fish species originating from the Atlantic have the same prob-

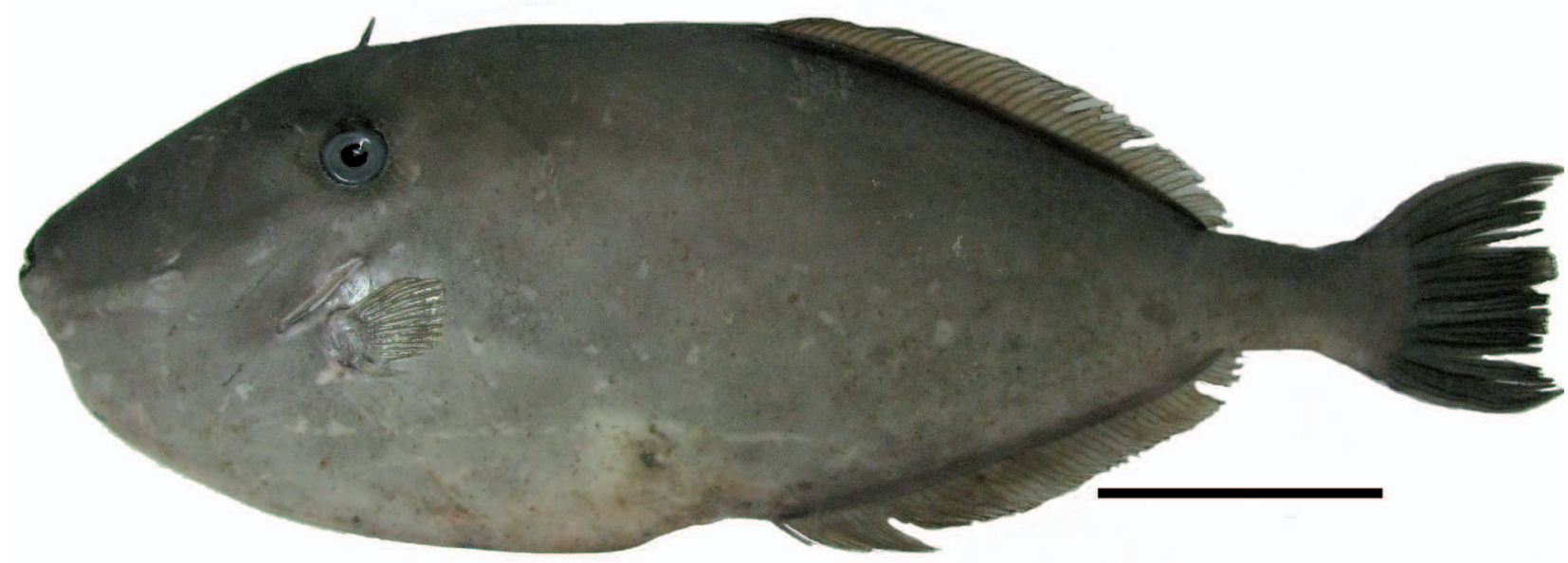

Fig. 2. Aluterus monoceros captured in the Gulf of Tunis (ref. No. Alu-mon.01), scale bar $=100 \mathrm{~mm}$ 
Table 1

Morphometric measurements, and meristic counts of Aluterus monoceros from northern Tunisian coast compared with data from published sources

\begin{tabular}{|c|c|c|c|c|c|c|c|c|c|c|c|c|}
\hline \multirow[b]{2}{*}{ Measurements } & \multicolumn{2}{|c|}{ Present study } & \multicolumn{2}{|c|}{$\begin{array}{l}\text { Berry and Vogele } \\
1961\end{array}$} & \multicolumn{2}{|c|}{$\begin{array}{c}\text { Quéro } \\
\text { and Laborde } \\
1996\end{array}$} & \multicolumn{2}{|c|}{$\begin{array}{c}\text { Galeote et al. } \\
1996\end{array}$} & \multicolumn{2}{|c|}{$\begin{array}{l}\text { De la Cruz- } \\
\text {-Agüero } \\
\text { et al. } 2006\end{array}$} & \multicolumn{2}{|c|}{$\begin{array}{r}\text { Gallart and } \\
\text { Vicent } 2009\end{array}$} \\
\hline & $\mathrm{mm}$ & $\% \mathrm{SL}$ & $\mathrm{mm}$ & $\% \mathrm{SL}$ & $\mathrm{mm}$ & $\% \mathrm{SL}$ & $\mathrm{mm}$ & $\% \mathrm{SL}$ & $\mathrm{mm}$ & $\% \mathrm{SL}$ & $\mathrm{mm}$ & $\% \mathrm{SL}$ \\
\hline Total length & 528 & - & - & - & 515 & - & 457 & - & 549 & - & 471 & - \\
\hline Standard length & 452 & 100.00 & $53-545$ & - & 450 & 100.00 & 391 & - & 505 & 100.00 & 384 & 100.00 \\
\hline Head length & 127 & 28.10 & - & $26.6-34.7$ & - & 26.7 & - & 28.6 & 138 & 27.33 & 116 & 30.21 \\
\hline Interorbital space & 45 & 9.96 & - & - & - & - & - & - & 41 & 8.12 & - & - \\
\hline Eye diameter & 22 & 4.87 & - & $3.8-4.2$ & - & 4.7 & - & 4.6 & 22 & 4.36 & 19 & 4.95 \\
\hline Eye to spine & 32 & 7.08 & - & $7.0-8.6$ & - & 6.8 & - & 6.1 & - & - & 30 & 7.81 \\
\hline Snout length & 119 & 26.33 & - & $23.4-27.5$ & - & 24.0 & - & 25.3 & 125 & 24.75 & 106 & 27.60 \\
\hline Internarinal space & 41 & 9.07 & - & - & - & - & - & - & 32 & 6.34 & - & - \\
\hline Caudal fin height & 33 & 7.30 & - & - & - & - & - & - & - & - & - & - \\
\hline Caudal fin length & 85 & 17.70 & - & $18.0-26.6$ & - & 16.7 & - & 16.3 & - & - & 70 & 18.23 \\
\hline Caudal peduncle length & 59 & 13.05 & - & - & - & - & - & - & 83 & 16.44 & 48 & 12.50 \\
\hline Caudal peduncle height & 34 & 7.52 & - & - & - & - & - & - & 36 & 7.13 & 32 & 8.33 \\
\hline Snout to vent & 248 & 54.87 & - & - & - & - & - & - & - & - & - & - \\
\hline Pectoral fin length & 43 & 9.51 & - & - & - & - & - & - & 141 & 27.92 & - & - \\
\hline Pectoral fin base & 19 & 4.20 & - & - & - & - & - & - & - & - & - & - \\
\hline Dorsal fin length & 159 & 35.18 & - & - & - & - & - & - & 162 & 32.08 & - & - \\
\hline Anal fin length & 165 & 36.50 & - & - & - & - & - & - & 167 & 33.07 & - & - \\
\hline Anal fin base & 161 & 35.62 & - & - & - & - & - & - & - & - & - & - \\
\hline Body height & 169 & 37.39 & - & $34.5-43.8$ & - & 35.0 & - & 34.5 & 172 & 34.06 & 149 & 38.80 \\
\hline Body depth & 53 & 11.73 & - & - & - & - & - & - & - & - & - & - \\
\hline Pre-pectoral length & 117 & 25.88 & - & - & - & - & - & - & 123 & 24.36 & - & - \\
\hline Pre-dorsal length & 255 & 56.42 & - & - & - & - & - & - & 128 & 25.35 & - & - \\
\hline Pre-anal length & 262 & 57.96 & - & - & - & - & - & - & - & - & - & - \\
\hline Inter-dorsal fins & 132 & 29.20 & - & - & - & - & - & - & - & - & - & - \\
\hline \multicolumn{13}{|l|}{ Counts } \\
\hline First dorsal & \multicolumn{2}{|r|}{ I } & \multicolumn{2}{|c|}{ II } & \multicolumn{2}{|c|}{ II } & \multicolumn{2}{|c|}{ II } & \multicolumn{2}{|c|}{ I } & \\
\hline Second dorsal fin rays & \multicolumn{2}{|c|}{45} & \multicolumn{2}{|c|}{$46-50$} & \multicolumn{2}{|c|}{49} & \multicolumn{2}{|c|}{46} & \multicolumn{2}{|c|}{49} & \multicolumn{2}{|r|}{47} \\
\hline Anal fin soft rays & \multicolumn{2}{|c|}{47} & \multicolumn{2}{|c|}{$47-52$} & \multicolumn{2}{|c|}{51} & \multicolumn{2}{|c|}{49} & \multicolumn{2}{|c|}{48} & & 51 \\
\hline Pectoral fin soft rays & \multicolumn{2}{|c|}{14} & & 14 & & 14 & & 4 & & 14 & & 14 \\
\hline Teeth on upper jaw & & 6 & & & & & & & & 6 & & \\
\hline Teeth on low jaw & & 4 & & & & & & & & 4 & & \\
\hline
\end{tabular}

$\mathrm{SL}=$ standard length.

ability to be recorded in the Mediterranean as Lessepsian fishes, and the warmer conditions of this sea increase the establishment of Atlantic species from southern latitudes. Additionally, Ben Raïs Lasram and Mouillot (2009) suggested that the Mediterranean is increasingly becoming a catch site for southern species.

In agreement with Ben Raïs Lasram and Mouillot's opinion (2009), some teleost species from the eastern Atlantic, are, at present, successfully established in the Mediterranean.

So, the blunthead puffer, Sphoeroides pachygaster (Müller et Troschel, 1848), first recorded in the Mediterranean near Mallorca (Oliver 1981), a decade after reached the Levant Basin (Golani 1996), and to date a substantial population is definitively established in Tunisian marine waters (Chérif et al. 2010). Additionally, the bluespotted seabass (or African hind), Cephalopholis taeniops (Valenciennes, 1828), known off the western Africa coast, was first recorded in the Mediterranean by Ben-
Abdallah et al. (2007) in the Gulf of Syrte; the species was recently found $1800 \mathrm{~km}$ eastward, in the Levant Basin by Salameh et al. (2009), who note the presence of several specimens over a period of nine years suggesting that $C$. taeniops has established a sustainable population in its new region.

This new capture of $A$. monoceros constituted a considerable extension of its previously known distribution within the Mediterranean. However, this new finding in this sea suggests that the species has found in the area favourable environmental conditions to reproduce (Francour et al. 1994). However, no sufficient data are available to state that a substantial population exists, at present, in the south-western Mediterranean.

\section{REFERENCES}

Al-Baharna W.S. 1986. Fishes of Bahrain. Ministry of Commerce and Agriculture, Directorate of Fisheries, Bahrein.

Ben-Abdallah A., Ben Souissi J., Méjri H., Capapé C., Golani D. 2007. First record of the bluespotted seabass, 
Cephalopholis taeniops (Serranidae) in the Mediterranean. Journal of Fish Biology 71 (2): 610-614.

DOI: $10.1111 / j .1095-8649.2007 .01504 . x$

Ben Amor M.M., Capapé C. 2008. Occurrence of a filefish closely related to Stephanolepis diaspros (Osteichthyes: Monacanthidae) off northern Tunisian coast (south-western Mediterranean). Cahiers de Biologie Marine 49 (3): 323-328.

Ben Raïs Lasram F., Mouillot D. 2009. Increasing southern invasion enhances congruence between endemic and exotic Mediterranean fish fauna. Biological Invasions 11 (3): 697-711. DOI: 10.1007/s10530-008-9284-4

Berry F.H., Le Vogele L.E. 1961. Filefishes (Monacanthidae) of the Western North Atlantic. Fishery Bulletin 61 (181): 57-109.

Bradaï M.N., Quignard J.-P., Bouain A., Jarboui O., Ouannes-Ghorbel A., Ben Abdallah L., Zaouali J., Ben Salem S. 2004. Ichtyofaune autochtone et exotique des côtes tunisiennes: Recensement et biogéographie. Cybium 28 (4): 315-328.

Chérif M., Ben Amor M.M., Bdioui M., Ben Salem S., Missaoui H., Capapé C. 2010. Additional records of the blunthead puffer, Sphoeroides pachygaster (Osteichthyes: Tetraodontidae) off the Tunisian coast (Central Mediterranean). Annales series Historia Naturalis 20 (1): 1-6.

De La Cruz-Agüero J., Cota-Gómez V.M., Melo-Barrera F.N. 2007. Occurrence of unicorn filefish Aluterus monoceros (L.) in the Gulf of California. Journal of Applied Ichthyology 23 (3): 284-285. DOI: 10.1111/j.1439-0426.2007.00838.x

Francour P., Boudouresque C.F., Harmelin J.G., HarmelinVivien M.L., Quignard J.-P. 1994. Are the Mediterranean waters becoming warmer? Information from biological indications. Marine Pollution Bulletin 28 (9): 523-526. DOI: 10.1016/0025-326X(94)90071-X

Galeote M.D., Otero J.G., Arias A.M. 1996. Primera cita para la Peninsula Ibérica de Aleturus monoceros (Linnaeus, 1758) (Pisces, Monacanthidae). Boletín del Instituto Espaňol de Oceanografía 12 (2): 151-153.

Gomez-Canchong P.G., Manjarrés L.M., Duarte L.O., Altamar J.E. 2004. Atlas pesquero del area norte del Mar Caribe de Colombia. Univesidad del Magadalena, Santa Marta, Colombia.

Guallart J., Vicent J.J. 2009. First record of the unicorn leatherjack Aluterus monoceros (Pisces, Monacanthidae) from the Mediterranean Sea. JMBA2-Biodiversity Records. http://journals.cambridge.org/jid MBD DOI:10.1017/S1755267209001183.
Golani D. 1996. The marine ichthyofauna of the eastern Levant-history, inventory and characterization. Israel Journal of Zoology 42: 15-55.

Golani D., Orsi-Relini L., Massuti E., Quignard, J.-P. 2002. CIESM Atlas of exotic species in the Mediterranean. Vol. 1. In: Briand F. (ed.). Fishes. CIESM Publications, Monaco.

Golani D., Öztürk B., Başusta N. 2006. Fishes of the eastern Mediterranean. Turkish Marine Research Foundation, Istanbul, Turkey.

Harmelin-Vivien M.L., Quéro J.C. 1990. Monacanthidae. Pp.1051-1056. In: Quéro J.C., Hureau M.L., Hureau J.-C., Karrer C., Tortonese E. (eds.) Check-list of the fishes of the eastern tropical Atlantic. Vol. II. UNESCO, Paris.

Lopez-Peralta R.H., Arcila C.A.T. 2002. Diet composition of fish species from Southern continental shelf of Colombia. Naga, Worldfish Center 25 (3-4): 23-29.

Oliver P. 1981. Sobre la aparición de algunos peces raros en las Islas Baleares. Boletín del Instituto español de Oceanografía 7 (304): 59-63.

Quéro J.C., Laborde J.L. 1996. Premier signalement en Atlantique Nord-Est, d'Aluterus monoceros (Tetraodontiformes, Monacanthidae). Cybium 20 (1): 107.

Quéro J.C., Porché P., Vayne J.J. 2003. Guide des poissons de l'Atlantique européen. Les Guides du naturaliste. Delachaux et Niestlé, Lonay, Paris.

Quignard J.-P., Tomasini J.A. 2000. Mediterranean fish biodiversity. Biologia Marina Mediterranea 7 (3): 1-66.

Salameh P., Sonin O., Golani D. 2009. First record of the African hind (Cephalopholis taeniops) (Pisces: Serranidae) in the Levant. Annales, series Historia Naturalis, 19 (2): 151-154.

Smith M.C., Heemstra P.C. 1986. Smiths'sea fishes. SpringerVerlag, Berlin, Heidelberg, New York, London, Paris, Tokyo.

Zouari-Ktari R., Bradai M.N., Bouain A. 2008. The feeding habits of the Lessepsian fish Stephanolepis diaspros (FraserBrünner, 1940) in the Gulf of Gabès (eastern Mediterranean Sea). Cahiers de Biologie marine 49 (4): 329-335.

Received: 25 March 2011

Accepted: 19 May 2011

Published electronically: 30 September 2011 